\title{
Religious Extremism as a Cause of Armed Conflicts: Indicators and Early Warning Systems
}

\section{Náboženský extremismus jako příčina ozbrojených konfliktů: indikátory a systémy včasného varování}

\section{Josef Kraus}

Abstract: The main topic and focus of this article is to identify the most relevant indicators of the rise of religious extremism as an important cause of armed conflicts. A religiously motivated conflict is a relevant topic in modern security studies and research. Conflict prevention using the early-warning indicators identified in this article might be interesting for the security expert community. In the article chosen methodology is available with the recommendation to following research in the examined field.

Abstrakt: Hlavním cílem tohoto textu je identifikovat nejčastěji využíváné a nejrelevantnější indikátory vzestupu náboženského extremismu ve společnosti jakožto důležité př́činy ozbrojených konfliktů. Nábožensky motitovaný konflikt je důležitým tématem současného bezpečnostního výzkumu. Jeho prevence za použití systému včasného varování opřeného právě o dílčí indikátory je tak pro bezpečnostní komunitu velice zajímavá. Tento článek představuje vybrané metodiky a doporučení pro další navazující výzkum celé problematiky.

Key words: $\quad$ Early Warning System; Extremism; Methodology; Prediction; Religious Conflict; Security Indicators.

Klíčová slova: Systém včasného varování; extrémismus; metodologie; predikce; náboženský konflikt; bezpečnostní indikátory. 


\section{INTRODUCTION}

Religion plays a pivotal role in the lives of many, with over $70 \%$ of the world population identifying as members of a religious community. Religion influences the values, beliefs and behaviours of groups and individuals both within the humanitarian sector and within its operating environment. Opinions, values, understanding and actions can influence the risk environment " - and the armed conflict as well. ${ }^{1}$ The conflict, in general, can be defined as „an expression of the heterogeneity of interests, values and beliefs that arise as new formations generated by social change come up against inherited constraints." 2 Religion (or faith as defined) is one of the main sources of conflict between and among different religious groups. Moreover, the ethnic dimension often plays the same role in combination with religion. It is a matter of identity and narratives for both individuals and communities. Perceptions of prejudice, victimhood, and discrimination are central in the dynamics of structural, physical and cultural violence. ${ }^{3}$ Finding a purely religious conflict is nothing easy. Usually, there are plenty of reasons provoking violence and many other dimensions of conflict than religion. So, to define a religious conflict, there is a need to view it as a complex phenomenon that engages a combination of contested domains, including power, personality, space or place, and group identity. Also, a distinction should also be drawn between the root cause/s of the religious conflict (what is contested) and how the conflict is discursively or narratively framed. There is also the need to distinguish between conflict and competition. Very simple, we can say a conflict is religious when a conflict in which religion is also involved occurs. We can then avoid the questions when a conflict is religious and when is it political/ethnic since the definition allows the conflict can be both. If we focus on actors or agents of religious conflict, there have to be two or more groups that derive from identifiably separate religions, separate factions within the same religion (sectarianism), the same faction within a religion, and secular authority. ${ }^{4}$

Religion can be just one dimension or cause of armed conflict, but when and how we can identify or predict it is becoming a threat for regional or state security? The process of radicalization can provide to an analyst a movement or social tendency to follow in society. Radicalization is the process by which individuals are introduced to an overtly ideological message and belief system that encourages movement from moderate, mainstream beliefs toward extreme views. Radical thinking is not a crime in itself. Sympathizing

1 European Interagency Security Forum. 2014. Security Risk Management and Religion: Faith and Secularism in Humanitarian Assistance, Insecurity Insight, pp. 2, Available at: http://www. insecurityinsight.org/aidindanger/wp-content/uploads/2014/08/EISF_Security-RiskManagement-and-Religion_-August-2014.pdf

2 Ramsbotham, O., Woodhouse, T. and Miall, H. 2005. Contemporary Conflict Resolution. 2nd edn. Cambridge and Malden: Polity, pp. 17

3 British Academy. 2015. The Role of Religion in Conflict and Peacebuilding, London. ISBN 978-0-85672618-7. p. 9.

4 MAYER, Wendy. 2013. Religious Conflict from Early Christianity to the Rise of Islam. Arbeiten Zur Kirchengeschichte: De Gruyter. ISBN 9783110291780 pp. 2-4 
with radical thinking does not necessarily lead to violence or terrorist action. However, radical thinking becomes a threat to national security when it leads an individual to espouse or engage in violence as a means of achieving political, ideological or religious goals. ${ }^{5}$ Following the religious radicalization process can be a crucial part of any kind of warning system focusing on religious extremism as a threat or a cause of armed conflict. The main goal of this article is to explain and describe the functions of different kinds of early warning systems and conditions for their application towards chosen society in identifying risks of armed conflict based on religious extremism. Also, another goal of this article is to identify the most relevant indicators of the rise of religious extremism as an important cause of armed conflicts in general. Further case studies can verify this approach and propriety of chosen indicators. This contribution is limited only on providing the framework for future work of analysts and experts on state or regional security.

\section{INDICATORS AND THE EARLY WARNING SYSTEMS}

Indicators or the early warning signals based on the developed early warning systems (EWS) are often used in the spheres of intelligence, predictive analysis or prevention. Identification of those and their following can help the state authority, international organisations, NGOs and expert individuals to be in touch with an examined object affected society, a regional security complex, a state etc. Especially in the case of conflict prevention, EWS and radicalisation indicators are widely used.

There are many layers or levels for examining and identifying proper indicator leading to the detailed observation of the chosen topic. Also, from the perspective of methodology, many different approaches can be used. Different tools provide different outcomes and can be used for different kinds of research and analysis. To predict or to monitor a violent conflict, early warning systems generate indicators in a variety of ways. Hagmeyer-Gaverus and Weissmann ${ }^{6}$ identify three main methods or models used to monitor and forecast developments in countries and crisis regions:

1. The database model based on statistical indicators, often time series data, provided on an annual basis by international organisations such as the World Bank and the United Nations.

2. Models using expert knowledge to forecast trends. The expert model bases its information on questionnaires and interviews, thus creating a separate set of indicators. Expert models usually obtain information from a wide range of informants in a regular, quick and standardised way, frequently used by NGOs, think-tanks and other.

5 Royal Canadian Mounted Police. Terrorism and Violent Extremism Awareness Guide, p.6, Available at: http://www.rcmp-grc.gc.ca/en/terrorism-and-violent-extremism-awareness-guide

6 HAGMEYER-GAVERUS, Gerd and Mikael WEISSMANN. 2003. Early Warning Indicators for Preventive Policy - a new approach in Early Warning research. SIPRI, Working Paper, Available at: https://www. diva-portal.org/smash/get/diva2:967529/FULLTEXT01.pdf 
3. News-wire monitoring/analysis systems that assess the risk of conflict through systematic machine coded coverage of news services such as Reuters.

This mainly quantitative approach can be very useful, especially with the existence of fulfilled database or advanced predictive models. Except for the method no. 2, there is just very limited space for regional experts to influence the outcome of an analysis. It is very much critical for the other two methods to depend on the relevant data and complete datasets for threat evaluation. The methods are very vulnerable towards data put into the process of its evaluation. Without combining it with experts supervision (or method no. 2), there might occur a problem with incorrect interpretation and evaluation of pure statistics. That is why the combination of quantitative and qualitative approaches are widely used for conflict prevention and conflict prediction systems or EWS in general.

SIPRI, the Stockholm International Peace Research Institute - the independent resource on global Security, ${ }^{7}$ works with two approaches (database and expert models) together combined increasing the accuracy of forecasts by including both short- and long-term data in the analysis. Statistical data are perfect for long-term predictions while for an extended forecasting model; however, short-term development data are essential. Such data cannot be obtained from country statistics, but only through observation of daily political, economic, and other events. This method is used for selecting and short-term indicators that are best suited to measure changes in areas such as political and economic performance, ethnic or religious issues, and human rights.

On the other hand, the purely quantitative approach is represented by a Global Model for Forecasting Political Instability (known as PITF) funded by the Central Intelligence Agency and hosted by the Center for Global Policy at George Mason University. ${ }^{8}$ The method is based on identification over 100 problem cases for the last half a century that had led to state failure, phenomenons like ethnic conflicts, regime changes, genocides etc. It can be a good tool for further analysis and definition of early warning signals (or indicators), but it is not a self-sufficient method for generating full-scale EWS. That is why majority of the projects, such as IGAD's Conflict Early Warning and Response Mechanism (CEWARM ${ }^{9}$ ) or Network for Ethnic Monitoring and Early Warning (EAWARN ${ }^{10}$ ) are based on a combination of both approaches adapted to local conditions or examined cases and regions.

Oliver Walton ${ }^{11}$ from the Governance and Social Development Resource Centre provides a list of general indicators for potential risks to security based on his research and literature retrieval. The list is divided into nine categories:

- Justice and human rights

7 Ibid.

8 See http://scip.gmu.edu/a-global-model-for-forecasting-political-instability/

9 See https://cewarn.org/index.php/about-cewarn

10 See http://www.incore.ulst.ac.uk/services/cds/metadata/eawarn.html

11 WALTON, Oliver. 2011. Helpdesk Research Report: Early Warning Indicators of violent conflict, Governance and Social Development Resource Centre, Avalable at: http://www.gsdrc.org/docs/ open/hd777.pdf 
- Socio-cultural factors

- Internal security setting

- Geopolitical setting

- Military and security

- Environment and resource management

- Governance and Political Stability

- Socio-economic factors

- Regional and Country-Specific factors

From the perspective of religious extremism, some are more and some less relevant. There is a need to distinguished those according to local conditions. For instance, the military and security category can be irrelevant for homogenous societies without a history of ethnic-religious conflict on its territory, while for those recently affected by civil war, uprising or any kind of armed violence with religious dimension this category can be very much relevant and risky.

Walton also works with a division of conflict early warning indicators into five categories with basic characteristics:

- Demographic (Sudden demographic changes and displacement/movements of people, increasing ,territoriality“ of groups/peoples)

- Economic (Short-term and long-term changes in the economic performance of a country or a region, increase in poverty or inequality, the rise of the unemployment rate, economic shocks or financial crises)

- Policy-Related (Deliberate acts of governments against a specific group or region, destruction or desecration of religious sites, active discrimination or legislation favouring one group over another, potentially destabilising referendums or elections, government "clamp-downs")

- Public Opinion or "Social Factors“ (a rise in „societal“ intolerance and prejudice, an increase in numbers of demonstrations or rallies)

- External (intervention or support on behalf of one of the parties/groups by an external actor, - diffusion“ or "contagion“ of ideologies or conflicts in neighbouring regions, an influx of refugees from a conflict in a neighbouring country).

Naturally, these categories need more operationalisation before being used for database creation. In that case, there would be a need to implement a security category of any kind in it. Can be part of the policy related or the social factors categories with special focus on the level of violent or politically motivated criminality, for instance. On the other hand, the external category seems to be very wide, broad and general in Walton's conceptualization. In many current conflicts, interference from abroad plays a crucial role in conflict escalation. 
The Institute for Safety, Security and Crisis Management ${ }^{12}$ has brought a detailed framework for radicalization and recruitment identification and counter-radicalization strategy combining quantitative and qualitative techniques. Its definition of man categories are very much similar to Walton's but bringing three different levels or layers for radicalisation identification:

1. External level including political, economic and cultural causes of radicalisation,

2. Social level with relative deprivation, social identification and network dynamics,

3. Individual level and its psychological characteristics, personal experience and rationality;

The special focus of this concept is put on recruitment and trigger events. It also provides the diversification of approaches according to the level of the causal factors. The first and the second level can be more examined with quantitative techniques, while the third layer - the individual one - is mainly based on a quantitative and multi-disciplinary approach. But still, there is a noticeable connection and interaction among those three levels, or at least between two different layers. But also some do not affect others at all. External factors manifest themselves independently of the individual. They shape and constrain people's environment, but individuals have an only minor influence on their environment. External factors do not have a direct effect on individual behaviour. A complex interaction between factors at the various levels is likely to be crucial for the intensity of the readiness for radicalisation. Social factors play an important intervening role in the relation between external factors and radicalisation. For example, stigmatisation of Islam in the media, an external cultural factor, is likely to impose a stronger radicalising force on Muslims than on non-Muslims. At the individual level, psychological characteristics, personal experiences and rationality influence how people respond to their social and external environment.

All the factors mentioned above and categories need detailed operationalisation to be usable for both quantitative and qualitative research. But, the identification of the indicators is more need for the quantitative approach than the qualitative one. Plus, it needs permanent monitoring of those for capturing the threat of rising radicalisation of society and predicting threats. The prediction and forecasting of risks and threats is also something worth mentioning in the case of EWI. Segell ${ }^{13}$ speaks about three broad types of methodologies for predicting and forecasting acts or events that have not been identified: 1) trends and patterns, 2) frequency, and 3) probability. All three have to gather data within a specific context to be passed on for an actionable operation. This approach is very much used by intelligence services for developing and establishing warning systems world wide.

12 Institute for Safety, Security and Crisis Management, 2008. Radicalisation, Recruitment and the EU Counter-radicalisation Strategy, Transnational Terrorism, Security and the Rule of Law, Available at: http://www.gdr-elsj.eu/wp-content/uploads/2014/02/doc2-WP4-Del-7.pdf

13 SEGELL, Glen M., 2005. Intelligence Methodologies Applicable to the Madrid Train Bombings, 2004, International Journal of Intelligence and Counter Intelligence, 18, 221-238pp. 


\section{THE RADICALISATION OF AN INDIVIDUAL}

There is another approach in preventing religious radicalisation as conflict prevention. Focusing on an individual instead of society can bring a completely different set of indicators or warning signals. Allison Smith ${ }^{14}$ identifies several potential risk factors for individuals attempting to engage in terrorism (group-based or lone-wolf). Although the factors are highly connected to armed violence and terrorism itself and not to radicalism in general, it is still valuable for the process of radicalisation of an individual.

- Having a History of Criminal Violence

- Having a Criminal History

- Having Been Involved With a Gang or Delinquent Peers

- Having a Terrorist Friend

- Being a Member of an Extremist Group for an Extended Period

- Having a Deep Commitment to an Extremist Ideology

- Having Psychological Issues

- Being Unemployed

- Having a Sporadic Work History

- Having Less Education

- Having a Lower Social Economic Status

- Failing to Achieve One's Aspirations

- Having Trouble in Romantic Relationships

- Having Trouble in Platonic Relationships

- Having Been Abused as an Adult

- Being Distant From One's Family

Many of those are based on socio-economic and psychological problems causing a frustration of an individual. Especially for those territories affected by armed conflict, having military experience ${ }^{15}$ is also identified as a potential risk factor leading to violence.

The Royal Canadian Mounted Police provides another set of indicators for violent radicalisation from the criminology perspective. ${ }^{16}$

- Significant changes of interests;

- Breaking relational ties, social isolation, change in peer groups and activities;

- Change in the way of thinking and interacting with others;

- Rejection of the State (politics and social values);

- Participating in radical activities or demonstrations and using extremist language;

14 SMITH, Allison. 2018. Risk Factors and Indicators Associated With Radicalization to Terrorism in the United States: What Research Sponsored by the National Institute of Justice Tells Us, National Institute of Justice, Available at: https://www.ncjrs.gov/pdffiles1/nij/251789.pdf

15 For the purpose of Smith's reasearch, military experience in US reality means mainly the military service in general. But, in conflict areas any experience of participation on armed conflict in general might be considered being a risk factor.

16 Ref. 12 
- Attending private meetings;

- Overconsumption of hate and violent propaganda images and videos on the Internet;

- Possession of propaganda material promoting violence;

- Segregation and antagonism („Us against Them“);

- Adhering to hatred and violence;

- Glorification of violence or sacrifice;

- Perpetration of minor crimes motivated by the rejection of governments and society;

- Change in appearance and dress style;

- Use of new names or pseudonyms in social media and personal environment;

These two sets of factors are very much similar to each other accenting psychological and social indicators, just the very close surrounding of an individual can notice. From the perspective on a general analysis of the environment (regional, state-level) affected by the threat of radicalisation and religious violence, it is impossible to observe and examine population in general according to individual factors. On the other hand, those can be very much helpful for local authorities to identify risky individuals and their possible networking providing broader statistics at the national level.

\section{THE USE OF INDICATORS AND EWS IN RELIGIOUS CONFLICT PREVENTION}

One of the methods used for predictions and identification of the threat of religious extremism in society is situation analysis. Gerrie ter Har and Stephen Ellis ${ }^{17}$ break religion down into four components that should be observed, monitored and analysed:

- Religious ideas: The perceptions of the universe, the world, life, nature, evil, the sacred, up to and including the virtues and values that guide actions.

- Religious practices: The actions, customs, places and objects that link perceptible reality with imperceptible reality.

- Religious organisations: The religious movements, communities and organisations, their leaders and the networks in which they cooperate.

- Religious experiences: People's experiences in relation to the transcendent. The transcendent here is a generic term for the ultimate, the divine, spirits, ancestors and gods. Religious experience can be at the root of transformations, both individually and collectively.

17 Gerrie ter Haar \& Stephen Ellis, "The role of religion in development. Towards a new relationship between the European Union and Africa", European journal of development research, 18, no. 3 (2006): 351-367. 
Based on the obtained data, the threat analysis has to follow. The crucial question is whether, and how, religion can impact on the threat itself and on the vulnerability of an agency or individual. ${ }^{\mathbf{1 8}}$ The analysis is based on three analyst sub-questions related to each other in the triangle of threat identification - diagram 1.

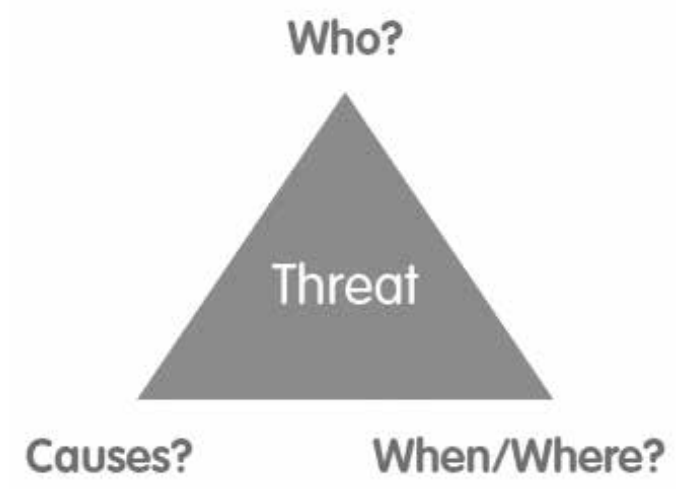

Diagram 1: Triangle of threat identification

The question "who" is related to a perpetrator of the threat and also to the potential or real victims. There is scope to examine whether religion is a motivating factor for the perpetrators or if it influences the selection of victims. "When and where" deals with the time and space - Is the threat more likely to occur in certain areas? Is there a link between threat and the religious composition of the population in that area? Are there particular locations of operation where threats are most likely to occur? And the last but not least question asking for "causes“, roots and drivers of identified threats. In areas of religious tension, religion can be one of these drivers or underlying causes.

The problem again is how to operationalise terms and layers mentioned above and put them into a proper pattern to be followed. It can provide a good framework for going deeper into the analysis of the examined phenomenon.

\section{CONCLUSION}

This article provides the basic background for the early warning system creation for further case studies, systematic intelligence analysis or conflict prevention. There are two main approaches to EWS creation and indicators identification - a quantitative one and a qualitative one. Some systems work with quantitative approach only providing warning indicators and redlines based on pure statistics. The problem is, there is just

18 lbid. 
a small space for regional experts to influence the outcome, while it is very much needed during the process of threat evaluation. The pure qualitative approach can miss the important macro view over the state or regional security. Especially, in the economy and demography, the statistics can provide different and much wider perspective. So, only the combination of two approaches seems to be ideal in creating the EWS in general.

Focusing on the topic of religious extremism as a cause of conflict and threat to national or regional security, mainly the process of society radicalisation has to be analysed. Religion itself is a very amorphous issue to be examined; that is why the religious radicalisation is difficult to handle. The theories of political radicalisation can help to prepare the proper framework for it. There are three layer or levels at which the process should be analysed or observed by a multi-disciplinary approach. Individual level focused on personal issues connected to psychology and sociology, social level dealing with the society as a whole, its tendencies, development and even statistics, and last but not least the external level including political, economic and cultural causes of radicalisation and its spill-over effect from abroad. This approach needs a continual observation of the set of indicator not only by statistics but also by regional experts on politics, sociology and psychology.

It is very difficult to bring a general scheme and system applicable to every region and society potentially facing the threat of religious extremism causing armed conflict. Local conditions should be taken into account, otherwise risking too much general and dysfunctional EWS. Only case studies with the general framework and local mutations can provide relevant outcomes and suitable system for conflict prevention of any kind, but religious dimension and cause needs special attention due to amorphous essence of the phenomenon.

This paper was elaborated as a part of the research project SIVARBAL (Proposal of the system of indicators of early warning for possible crisis situations in Balkan), funded by the Defence research of the Ministry of Defence of the Czech Republic.

Author: Josef Kraus, Ph.D., born in 1985. He graduated from the bachelor's, master's and doctoral studies in political science at the Faculty of Social Studies, Masaryk University. He still acts as an assistant professor at the Department of Security and Strategic Studies. He is also a scientific researcher at the International Institute of Political Science. At the same time he is a member of the editorial board of the Czech Military Review journal. He deals with the security problems of the Middle East region, with a focus on Islamic Republic of Iran and state terrorism research.

How to cite: KRAUS Josef. Religious Extremism as a Cause of Armed Conflicts: Indicators and Early Warning Systems. Vojenské rozhledy. 2019, 28 (3), 016-025. ISSN 1210-3292 (print), 2336-2995 (on-line). Available at: www.vojenskerozhledy.cz 